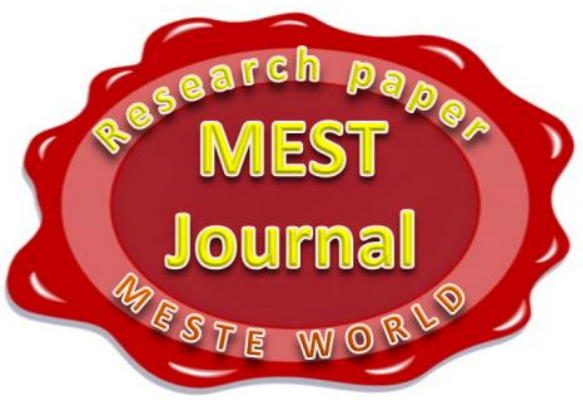

\title{
STATISTICAL RESEARCH WITHIN THE PERFORMANCE TESTING IN THE CRITICAL TRANSPORT INFRASTRUCTURE
}

\author{
Ladislav Novák \\ University of Žilina, Faculty of Special Engineering, Žilina, Slovakia \\ Mária Lusková \\ University of Žilina, Faculty of Special Engineering, Žilina, Slovakia
}

( ) MESTE NGO

JEL category: A23, 123, L26

\begin{abstract}
In the last years crisis management is dealing with many important problems. The current threats of countries, inhabitants, property and natural environment belongs to the most important issues. The extreme weather negative impacts and adverse consequences caused by accidents in technological processes and transport have become more and more frequent and intense events. In addition danger of extremism and terrorism, aimed at important object, is also expanding. In developed countries these objects are parts of critical infrastructure. Critical infrastructure sectors in different countries are not unified. In most of the countries the critical infrastructure includes information technologies, energy and transportation. In Slovakia the transportation sector consists of subsectors - road, water, aviation and railway transport.

The railway transport is an important subsector of the critical infrastructure. Its importance is unquestionable especially in the field of mass transportation and transportation of bulk substrata. Traditional methods, which were used in the past, were based on experience. The actual possibilities of computer technique enable to explore the railway transport performance through expert information systems. They are based on detailed statistical research. The paper will present the results of the researchers of the Faculty of Special Engineering, University of Žilina focused on the selection and testing the suitable distribution for stochastic events in railway transport. Based on the extensive statistical research the authors demonstrate that the driving time of trains in line sections is more suitable to be considered as random variable with Erlang distribution. The mentioned theoretical findings were used in development of software tool ASTRA that simulates railway transport in emergency situations.
\end{abstract}

Keywwords: Critical transport infrastructure, statistical research, risk management.

\section{INTRODUCTION}

Address of the corresponding author: Ladislav Novak

莑=” ladislav.novak@fsi.uniza.sk
The issues of critical infrastructure protection are dealing with quite a number of limitations especially with assessment of economic 
effectiveness. Assignment of the railway objects among the critical infrastructure elements is demanding multidiscipline task. In standard conditions we would suppose that it is sufficient to select objects that meet two or three defined criterions (length, intensity, capacity) and these can be indicated as critical infrastructure elements. But really this approach has to be completed by evaluation of vulnerability and other aspects. In the process of selecting prospective elements of critical infrastructure we use also various mathematical methods. Simulation of railway traffic on line sections eventually simulation of renewal of specific objects are part of them. The contents of this paper are focused on the long term experience of authors within development of simulation program dealing with modelling railway transport on railway line sections.

The statistic investigation of the train movement in the railway line section forms a part of contemporary approaches to the designing and modernisation of the railway lines. It has become more important above all in the application of methods dealing with the mass service and simulating of railway traffic. (Dvorak, Novak, \& Leitner, 2013)

\section{THE RAILWAY TRAFFIC AS A SYSTEM OF MASS SERVICE}

The railway traffic is being influenced by a series of external influences, the effect of which is not permanent, but accidental and temporary, without possibility of their simple mathematic formulation. Under influence of the damages in driving vehicles, wagons and technological appliances as well as under the effect of human factor and natural impacts the deviations in the train movement occur. Majority of deviations is represented by the delays and only a minimum of them arises e.g. by the shortening of riding times. So can be stated that both the individual riding times and the occupancy of the track sections will be random variables. (Novak, Dvorak, Leitner, \& Luskova, 2013)

In the available calculations the railway traffic is most often classified as a system of mass service $\mathbf{M} / \mathbf{M} / \boldsymbol{n}$, which represents the Poisson's process of entry and the exponential distribution of the service time.

The time gaps $\boldsymbol{t}_{\boldsymbol{i}}$ between the individual entries of trains into the track section represent the time intervals between the entries of the demands into the system of mass service.

The period of service is the period of occupancy $t_{o b s}$ of the track section by a concrete train whereas

$t_{\text {obs }}=t_{j}+t_{\text {tech }}$

where:

$\boldsymbol{t}_{j}$ is the riding time through the section,

$\boldsymbol{t}_{\text {tech }}$ is the operational technological times.

Though, generally known is only the relation between the average values of following quantities

$$
t_{o b s, p}=\eta t_{i, p}
$$

where:

$\boldsymbol{n}$ represents the working load of the track section,

$t_{i, p}$ represents riding time of the track section.

These approaches are being introduced by majority of authors. Calculations with the average values, though, restrict greatly the mathematic possibilities of solution. (Novak \& Luskova, 2012)

\section{FORMULATION OF THE PROBLEM AND HYPOTHESIS FOR ITS SOLUTION}

The riding time of a train through the track section is the basis variable. Being statistically valuated, both minimal and maximal values are found. This suggests the application of a theory on $6 \sigma$. This theory also deals with minimal and maximal (real) valuables of a random variable, but normally distributed. The theory guarantees, that $99.73 \%$ of all the values will be found in the very range $\pm 3 \sigma$ from the average value $(\sigma$ - standard deviation)

The application of this theory is as well supported by [2] the statement that "... models with the $\Gamma$ distribution of random variable are suitable for the situations where the minimal value of an interval is strictly given, e.g. by an interval of the following ride by the maximal permitted speed, and the 
addition is not sharply separated. It is enough to use the Erlang's distribution considering the parameter "a" as an integer".

However, another hypothesis suggests the possibility of replacement of the exponential distribution of the section time by the Erlang's distribution with the application of the theory on 6\%. (Brandalik \& Kluvanek, 1986)

Very interesting is the term of maximal permitted speed in comparison with the traditional calculations, which use so called "average" speed. The maximal permitted speed will correspond to the minimal riding time $\boldsymbol{t}_{j, \min }$, the adequate minimal time of engaging the track section $\boldsymbol{t}_{\text {obs,min }}$, and when taking into account the allowable working load $\boldsymbol{\eta}$ also the gap-length between the rides of two trains $\boldsymbol{t}_{i, \text { min }}$.

\section{VERIFICATION OF THE HYPOTHESIS ON THE ERLANG'S DISTRIBUTION OF THE RIDING TIME}

To verify the accepted hypothesis many wide statistic investigations of riding time have been made on 16 track sections during 20 days on the basis of the realized railway transport diagrams. The total number of values was nearly 11000 . The ridings time in individual track sections have been measured separately for slow, freight and express trains. (D-24, 1966) By each statistic set were calculated:

$$
\begin{array}{ll}
\boldsymbol{x}_{\boldsymbol{p}}- & \text { the arithmetic mean-average value, } \\
\boldsymbol{s}^{2}- & \text { dispersion variance, } \\
\sigma- & \text { standard deviation. }
\end{array}
$$

For the class calculation of distribution of frequency the following formulae were used:

$$
\begin{aligned}
& x_{p}=\frac{1}{n} \sum_{i=1}^{k} n_{i} x_{i} \\
& s^{2}=\frac{1}{n} \sum_{i=1}^{k} n_{i}\left(x_{i}-x_{p}\right) \\
& \delta=\sqrt{s^{2}}
\end{aligned}
$$

where

$n \quad$ - is the total frequency of the set (for relatively $n=100$ ),

$$
\begin{array}{ll}
\boldsymbol{n}_{i} & - \text { frequency of } \boldsymbol{i} \text {-class, } \\
\boldsymbol{k} & - \text { number of classes, } \\
\boldsymbol{x}_{i} & - \text { class symbol. }
\end{array}
$$

With respect to the above given assumption and preliminary courses of density curves in all sets has been measured the approximation by Erlang's and exponential distribution. To verify the assumption the $\chi^{2}$ test of goodness of fit has been used, where as the test criterion serves the random variable in the formula:

$\chi^{2}=\sum_{i=1}^{k} \frac{\left(x_{i}-n p_{i}\right)^{2}}{n p_{i}}$

where

$\boldsymbol{k}$ is number of classes,

$\boldsymbol{p}_{\boldsymbol{i}}$ - probability of $\boldsymbol{i}$ - the class in assumed distribution for the level of significance 0,05 .

The values of assumption $\boldsymbol{p}_{\boldsymbol{i}}$ for individual classes were measured according to the following relations:

- $\quad$ for the exponential distribution

$$
p_{i}=\int_{x_{d o l}}^{x_{h o r}} e^{-\lambda x} d x
$$

- for the Erlang's distribution

$$
p_{i}=\int_{x_{d o l}}^{x_{h o r}} \frac{b^{a} x^{a-1} e^{-b x}}{a !} d x
$$

where:

$$
\begin{array}{ll}
\boldsymbol{x}_{d o l} & \text { - is the class lower limit, } \\
\boldsymbol{x}_{\text {hor }} & \text { - class upper limit, } \\
\lambda & \text { - flow parameter, } \\
\boldsymbol{a}, \boldsymbol{b} & \begin{array}{l}
\text { - parameters of Erlang's } \\
\text { distribution. }
\end{array} \\
\lambda=1 / x_{p} \quad a=x_{p} b \quad b=x_{p} / s^{2}
\end{array}
$$

The calculations of all the value were measured via computer according to own algorithm. The integral was calculated by the Simson's method. Fig. 1 shows the histogram of frequency of riding times in one evaluated track section. It is obvious that the course distribution of riding times by slow, freight and express trains differ. (Černy \& Kluvanek, 1991) 


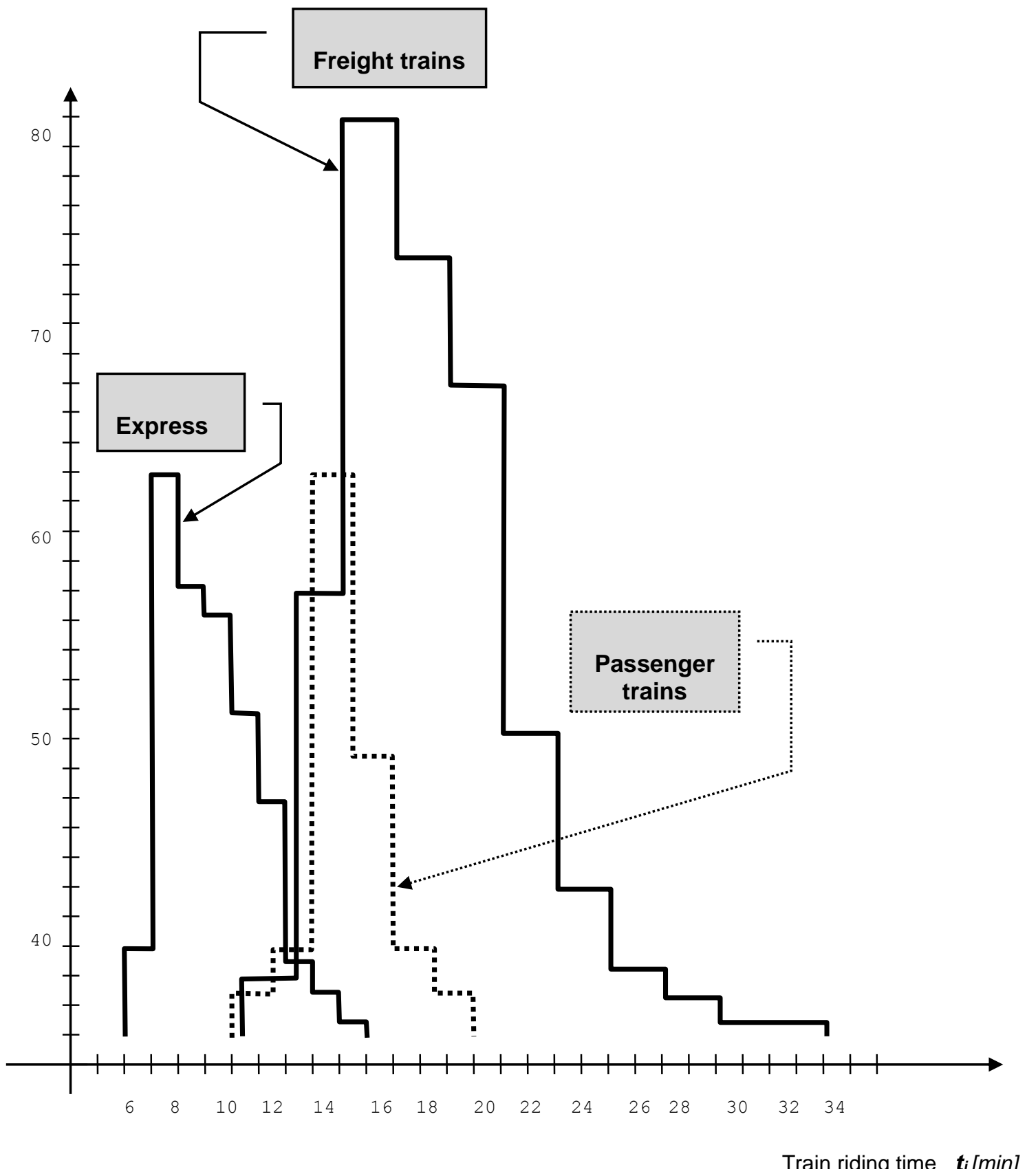

Fig. 1 Histogram of frequency of riding times $\mathbf{t}_{j}$ through track section

It is unique that the course of distribution of riding times does not correspond to the exponential distribution. This has also been proved by the results of approximation which has confirmed the unacceptability of the statement on the exponential distribution, in respect to the extremely negative values of $\chi^{2}$ test of goodness of fit table 1 Advantageous is the approximation by Erlang's distribution where 16 values fit very well. We can state that the theoretical model of random variable with the Erlang's distribution very suitably characterizes the tested quantity - the riding. 
Novak $D$. Performance testing in the critical transport infrastructure MEST Journal Vol. 2 No. 2 pp. 173-180

Table 1 The comparison of the evaluation results of statistic sets of riding times through the track sections

\begin{tabular}{|c|c|c|c|c|c|c|c|}
\hline \multirow{3}{*}{ Track Section } & \multirow{3}{*}{$\begin{array}{l}t_{p, j} \\
{[\mathrm{~min}]}\end{array}$} & \multirow{3}{*}{$s^{2}$} & \multirow{3}{*}{$\delta$} & \multicolumn{4}{|c|}{ Division } \\
\hline & & & & \multicolumn{2}{|c|}{ Exponential } & \multicolumn{2}{|c|}{ Erlang's } \\
\hline & & & & $\chi_{\text {emp }}^{2}$ & $\chi^{2} t$ & $\chi_{\mathrm{emp}}^{2}$ & $\chi^{2}$ \\
\hline Trenčianska Teplá - Dubnica & 6.72 & 2.51 & 1.58 & 167,799 & 12.59 & 2.9346 & 11.07 \\
\hline Dubnica - Trenčianska Teplá & 7.61 & 4.37 & 2.09 & 126,882 & 15.51 & 3.0423 & 14.0 \\
\hline Žilina zr. st. - Dolný Hričov & 11.15 & 8.01 & 2.83 & 174,985 & 12.59 & 6.2845 & 11.07 \\
\hline Dolný Hričov - Žilina zr.st & 11.33 & 7.94 & 2.82 & 173,404 & 12.59 & 4.3986 & 11.07 \\
\hline Turany - Kral'ovany & 12.77 & 10.67 & 3.27 & 161,440 & 14.07 & 4.0624 & 12.59 \\
\hline Kral'ovany - Turany & 14.46 & 13.77 & 3.71 & 159,276 & 15.51 & 4.0209 & 14.07 \\
\hline Ladce - Dubnica & 15.58 & 14.23 & 3.77 & 188,277 & 15.51 & 6.6429 & 14.07 \\
\hline Dubnica - Ladce & 16.15 & 12.17 & 3.49 & 209,072 & 15.51 & 3.6804 & 14.07 \\
\hline Krásno nad Kysucou - Čadca & 16.15 & 13.94 & 3.73 & 185,922 & 15.51 & 2.5870 & 14.07 \\
\hline Čadca - Krásno nad Kysucou & 16.18 & 11.54 & 3.40 & 234,728 & 15.51 & 12.3490 & 14.07 \\
\hline Vrútky - Varín & 16.59 & 15.31 & 3.91 & 204,165 & 15.51 & 12.3490 & 14.07 \\
\hline Varín - Vrútky & 17.49 & 15.62 & 3.95 & 201,880 & 15.51 & 7.0458 & 14.07 \\
\hline Púchov - Považská Bystrica & 18.55 & 13.80 & 3.71 & 240,641 & 15.51 & 6.9021 & 14.07 \\
\hline Považská Bystrica - Púchov & 18.62 & 15.18 & 3.90 & 225,724 & 15.51 & 7.5096 & 14.07 \\
\hline Lúky pod Makytou - Horní Lideč & 19.93 & 24.17 & 4.62 & 205,412 & 15.51 & 11.8584 & 14.07 \\
\hline Považská Bystrica - Bytča & 20.08 & 27.45 & 5.24 & 194,985 & 14.07 & 18.9283 & 12.59 \\
\hline Bytča - Považská Bystrica & 21.10 & 44.04 & 6.64 & 140,420 & 14.07 & 14.6035 & 12.59 \\
\hline Horní Lideč - Lúky pod Makytou & 22.92 & 58.71 & 7.66 & 98,234 & 15.51 & 3.0808 & 14.07 \\
\hline
\end{tabular}

Remark: The values in the tables are suitable for the values $\chi^{2}$ in the test

\section{THE APPLICATION OF THE THEORY O 6 SIGMA}

The courses of histogram and approximation show clearly that Erlang's distribution is oblique left. Hence follows that neither the average value of the riding time $t_{\mathrm{j}, \mathrm{p}}$ will be in the position $\pm \mathbf{3} \sigma$ between the minimal and maximal values of riding times. For the application of the above given theory were chosen the theoretical assumptions according to Fig.2.

On the basis of above given theoretical assumptions and of the obtained statistic sets were calculated the values of the standard deviance $\sigma$ and coefficient $\boldsymbol{k}_{1}$ for the individual track sections according to the relation:

$$
k_{1}=\frac{t_{j, p}-t_{j, \min }}{\delta}
$$

The results of calculations are introduced in Fig.2. We were successful to prove that there does exist a relation between minimal and maximal values of riding time through track section, measured by the use of the standard deviation $\sigma$, coefficient $\boldsymbol{k}_{1}=$ 1.84 .

At the same time was proved the relation of the standard deviance and the average riding time as $\sigma=\mathbf{0 . 2 5} t_{\mathrm{t}, \mathrm{p}}$ and was derived the relation

$$
t_{j, p}=1.85 t_{j, \min }
$$


Novak $D$. Performance testing in the critical transport infrastructure MEST Journal Vol. 2 No. 2 pp. 173-180

Table 2 The survey of the measured obtained values $\sigma$ and $k_{1}$ in the track section

\begin{tabular}{|l|c|c|c|c|}
\hline \multirow{2}{*}{\multicolumn{1}{|c|}{ Track section }} & \multicolumn{2}{c|}{$\begin{array}{c}\text { Times of occupancy } \\
\text { of the section }\end{array}$} & \multirow{2}{*}{$\mathbf{k}_{\mathbf{1}}$} \\
\cline { 2 - 3 } & $\mathbf{t}_{\mathrm{j}, \text { min }}[\mathbf{m i n}]$ & $\mathbf{t}_{\mathrm{j}, \mathrm{p}}[\mathbf{m i n}]$ & & \\
\hline Trenčianska Teplá - Dubnica & 4 & 6.72 & 1.58 & 1.72 \\
\hline Dubnica - TrenčianskaTeplá & 4 & 7.61 & 2.09 & 1.73 \\
\hline Žilina zr.st. - Dolný Hričov & 6 & 11.15 & 2.83 & 1.82 \\
\hline Dolný Hričov - Žilina zr.st & 6 & 11.33 & 2.82 & 1.89 \\
\hline Turany - Kralovany & 7 & 12.77 & 3.27 & 1.76 \\
\hline Kralovany - Turany & 8 & 14.46 & 3.71 & 1.74 \\
\hline Ladce - Dubnica & 9 & 15.58 & 3.77 & 1.75 \\
\hline Dubnica - Ladce & 9 & 16.15 & 3.49 & 2.05 \\
\hline Krásno nad Kysucou - Čadca & 9 & 16.15 & 3.73 & 1.92 \\
\hline Čadca - Krásno nad Kysucou & 9 & 16.18 & 3.40 & 2.11 \\
\hline Vrútky - Varín & 9 & 16.59 & 3.91 & 1.69 \\
\hline Varín - Vrútky & 10 & 17.49 & 3.95 & 1.90 \\
\hline Púchov - Považská Bystrica & 11 & 18.55 & 3.71 & 2.04 \\
\hline Považská Bystrica - Púchov & 11 & 18.62 & 3.90 & 1.95 \\
\hline Lúky pod Makytou - Horní Lideč & 10 & 19.93 & 4.62 & 2.02 \\
\hline Považská Bystrica - Bytča & 11 & 20.08 & 5.24 & 1.73 \\
\hline Bytča - Považská Bystrica & 11 & 21.10 & 6.64 & 1.52 \\
\hline Horní Lideč - Lúky pod Makytou & 11 & 22.92 & 7.66 & 1.69 \\
\hline
\end{tabular}

$F(x)$

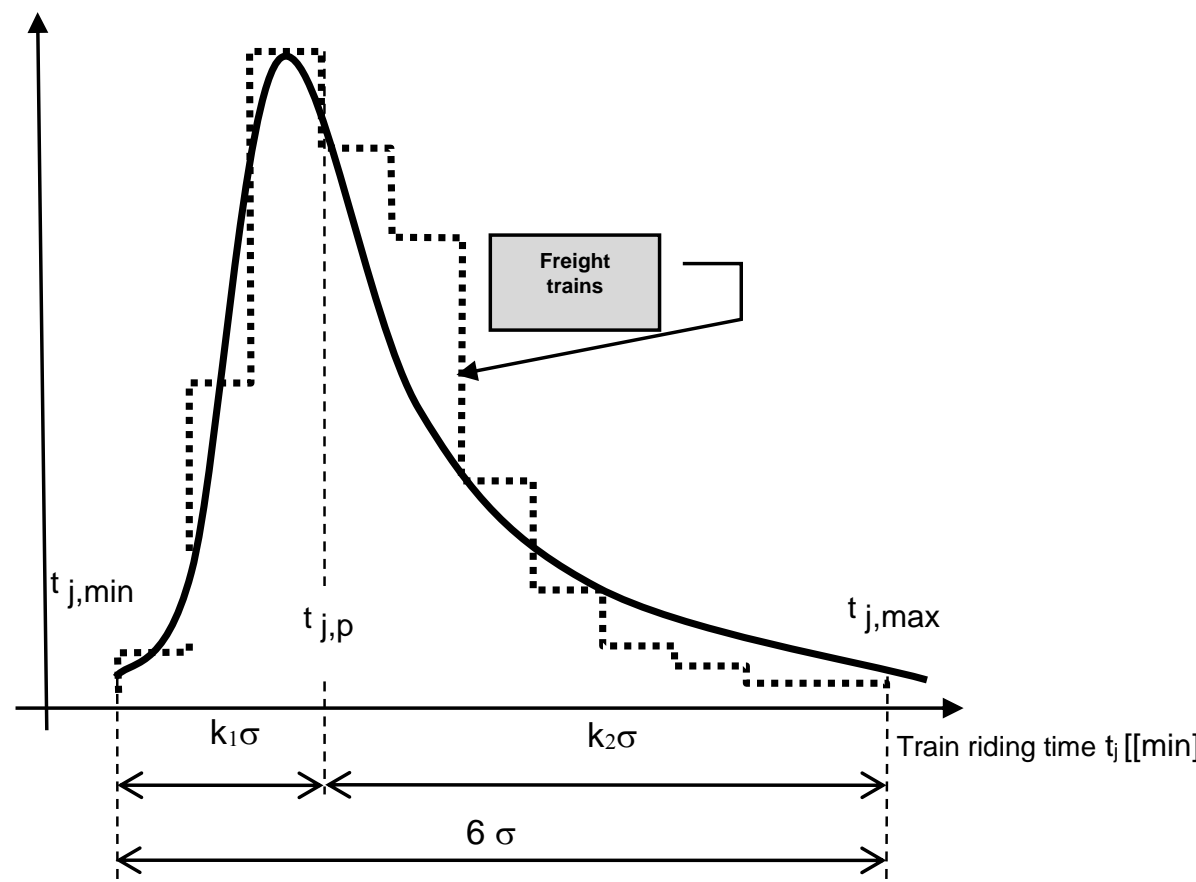

Fig.2 Theoretical outcomes for the calculation of the position of the average riding time $\boldsymbol{t}_{j, p}$ 
To verify the above given conclusions was evaluated the dependence of the average and minimum riding time in the mentioned track sections as

$$
k_{3}=\frac{t_{j, p}}{t_{j, \min }}
$$

The final value $\boldsymbol{k}_{3}=\mathbf{1 . 8 3}$ confirms for $99 \%$ the correctness and usability of the calculation of the average riding time according to the relation. (Danek \& Vonka, 1984)

\section{CONCLUSION}

On the basis of an extent statistic evaluation it is more accurate and suitable to characterize the riding time of the trains in track section $\mathbf{t}_{\mathrm{j}}$ as a random variable with the Erlang's distribution. On the basis of the derived relations and performed calculations and with the application of the theory $6 \sigma$ we were successfully to prove that there does exist a relation between minimal and average values of the riding time through the line section:

$$
t_{j, p}=1.85 t_{j, \min }
$$

The more accurate characterization of the mentioned constant is possible on the basis of statistic evaluation of further track sections eventually separately for one-way and both-way traffic, respectively for various types of traction in operation.

\section{WORKS CITED}

Brandalik, F., \& Kluvanek, P. (1986). Operační analýza v železniční dopravě. Bratislava: ALFA.

Černy, J., \& Kluvanek, P. (1991). Základy matematické teorie dopravy. Bratislava: SAV.

D-24. (1966). Predpisy pro zjišt'ovaní propustnosti zeleznicních trati. Praha: NADAS.

Danek, J., \& Vonka, J. (1984). Dopravní provoz železnic. Bratislava: ALFA.

Dvorak, Z., Novak, L., \& Leitner, B. (2013). The theoretical background for research of road transport elements vulnerability in Slovakia. TRANSBALTICA 2013. Vilnius, Litva: VGTU.

Novak, L., \& Luskova, M. (2012). Posibilities of statistic in anthrpogenic risks research in industrial area. Management 2012. Mladenovac, Seria.

Novak, L., Dvorak, Z., Leitner, B., \& Luskova, M. (2013). New approaches to simulation of railway transport in track section. TRANSBALTICA 2013. Vilnius, Litva: VGTU.

\section{ACKNOWLEDGEMENT}

This paper was supported by project:

APVV 0471-10 Critical Infrastructure Protection in Sector Transportation

Received for publication: $\quad 31.01 .2014$

Revision received: $\quad$ 03.06.2014

Accepted for publication: $\quad 23.06 .2014$

\section{How to cite this article?}

\section{Style - APA Sixth Edition}

Novak, L., \& Luskova, M. (2014, 07 15). Statistical research within the performance testing in the critical transport infrastructure. (Z. Čekerevac, Ed.) MEST Journal, 2(2), 173-180. doi:10.12709/mest.02.02.02.18 
Novak $D$. Performance testing in the critical transport infrastructure

MEST Journal Vol. 2 No. 2 pp. 173-180

Style - Chicago Fifteenth Edition:

Novak, Ladislav, and Maria Luskova. 2014. "Statistical research within the performance testing in the critical transport infrastructure." Edited by Zoran Čekerevac. MEST Journal (MESTE) 2 (2): 173180. doi:10.12709/mest.02.02.02.18.

Style - GOST Name Sort:

Novak Ladislav and Luskova Maria Statistical research within the performance testing in the critical transport infrastructure [Journal] // MEST Journal / ed. Čekerevac Zoran. - Belgrade : MESTE, 07 15, 2014. - 2 : Vol. 2. - pp. 173-180.

Style - Harvard Anglia:

Novak, L. \& Luskova, M., 2014. Statistical research within the performance testing in the critical transport infrastructure. MEST Journal, 15 07, 2(2), pp. 173-180.

Style - ISO 690 Numerical Reference:

Statistical research within the performance testing in the critical transport infrastructure. Novak, Ladislav and Luskova, Maria. [ed.] Zoran Čekerevac. 2, Belgrade : MESTE, 07 15, 2014, MEST Journal, Vol. 2, pp. 173-180. 